\title{
Pengaruh Model Pembelajaran Kooperatif Tipe CRH (Course Review Horay) dengan Pendekatan Scientific terhadap Motivasi dan Hasil Belajar Peserta Didik Kelas XI MIPA SMAN 2 Sidrap (Studi pada Materi Pokok Hidrokarbon)
}

\section{The Effect of the Cooperative Learning Model Type CRH (Course Review Horay) with Scientific Approach towards Motivation and Learning Achievement to Student in Class XI MIPA SMAN 2 Sidrap (Study on Hydrocarbon)}

\author{
${ }^{1)}$ Joulman Cipta Alief Anugrah, ${ }^{2)}$ Sugiarti, ${ }^{3)}$ Taty Sulastry \\ 1,2,3) Jurusan Kimia Fakultas Matematika dan Ilmu Pengetahuan Alam \\ Universitas Negeri Makassar, Jl. Dg Tata Raya Makassar, Makassar 90224 \\ Email: joulmananugrah@gmail.com
}

\begin{abstract}
ABSTRAK
Penelitian ini merupakan penelitian eksperimen semu (quasi experimental) yang bertujuan untuk mengetahui pengaruh model pembelajaran kooperatif tipe CRH dengan pendekatan scientific terhadap motivasi dan hasil belajar peserta didik kelas XI MIPA SMA Negeri 2 Sidrap. Desain penelitian yang digunakan adalah "pretest posttest-only control group design". Populasi penelitian ini adalah peserta didik kelas XI MIPA SMA Negeri 2 Sidrap yang terdiri dari lima kelas. Teknik pengambilan sampel yang digunakan yaitu class random sampling sehingga sampel penelitian ini adalah kelas XI MIPA 1 sebagai kelas eksperimen dan kelas XI MIPA 2 sebagai kelas kontrol dengan jumlah peserta didik masingmasing 36 orang. Variabel bebas pada penelitian ini adalah model pembelajaran kooperatif tipe $\mathrm{CRH}$ dan variabel terikatnya yaitu motivasi dan hasil belajar. Data motivasi dan hasil belajar yang diperoleh dianalisis dengan menggunakan statistik deskriptif dan statistik inferensial. Pengujian hipotesis untuk pengaruh model pembelajaran kooperatif tipe $\mathrm{CRH}$ dengan pendekatan scientific terhadap motivasi belajar peserta didik menggunakan uji-t. Pengujian hipotesis untuk pengaruh model pembelajaran kooperatif tipe $\mathrm{CRH}$ dengan pendekatan scientific terhadap hasil belajar peserta didik menggunakan Mann-Whitney. Hasil pengujian menunjukkan adanya pengaruh model pembelajaran kooperatif tipe $\mathrm{CRH}$ dengan pendekatan scientific terhadap motivasi hasil belajar peserta didik kelas XI MIPA SMA Negeri 2 Sidrap (Studi pada Materi Pokok Hidrokarbon).
\end{abstract}

Kata kunci: Model Pembelajaran Kooperatif tipe CRH, Pendekatan Scientific, Motivasi, Hasil Belajar 


\begin{abstract}
This study is a quasi-experimental research (quasi-experimental), which is aims to determine the effect of cooperative learning model type CRH with scientific approach toward motivation and learning achievement of student's class XI MIPA SMA Negeri 2 Sidrap. The study design used is "pretest posttest-only control group design". These study population were all the students of class XI MIPA SMA Negeri 2 Sidrap which is consists of five classes. The sampling technique used is class random sampling so that the sample are a class XI MIPA 1 as an experimental class and class XI MIPA 2 as control class with the number of students each 36 peoples. The independent variable in this study is cooperative learning model type $\mathrm{CRH}$ and the dependent variable is motivation and learning achievement of student's. Motivation and learning achievement's data were analyzed using descriptive statistics and inferential statistics. Hypothesis test for effect of cooperative learning model type $\mathrm{CRH}$ with scientific approach toward motivation of student's using t-test. Hypothesis test for effect of cooperative learning model type $\mathrm{CRH}$ with scientific approach toward learning achievement of student's using Mann-Whitney test. The result shown that there is an effect of cooperative learning model type CRH with scientific approach toward motivation and learning achievement of student Class XI MIPA SMA Negeri 2 Sidrap (Study on Hydrocarbon).

Keywords: Cooperative Learning Model type CRH, Scientific Approach, Motivation, Learning Achievement
\end{abstract}

\section{PENDAHULUAN}

Pembelajaran

pendekatan scientific $(5 \mathrm{M})$ yaitu mengamati, menanya, mengasosiasi, mengumpulkan data dan mengomunikasikan merupakan proses pembelajaran yang kreatif dan variatif yang dapat digunakan pada hamper semua model pembelajaran atau metodes seperti pada model CRH. Melalui pendekatan ini akan mengubah cara guru mengajar yang monoton menjadi pembelajaran yang mengaktifkan peserta didik dalam berbagai variasi metode sehingga peserta didik lebih termotivasi dalam belajar yang berimplikasi terhadap hasil belajar agar dapat meningkat.

Salah satu pelajaran yang terkadang menimbulkan kejenuhan bagi peserta didik dalam pembelajaran sehingga hasil belajar sangat rendah dikarenakan sulit dipahami oleh peserta didik adalah mata pelajaran kimia. Hal tersebut sesuai dengan hasil wawancara dengan beberapa peserta didik kelas XI SMA Negeri 2 Sidrap mengatakan bahwa pelajaran kimia merupakan pelajaran yang sulit untuk dipahami, metode dan model pembelajaran yang digunakan dalam proses pembelajaran tidak bervariasi, sehingga membuat peserta didik menjadi bosan dan jenuh dalam proses pembelajaran yang membuat rendahnya hasil belajar. Apalagi pada materi pokok hidrokarbon yang merupakan salah satu materi pokok dalam pelajaran kimia yang dipelajari di kelas XI semester 1. Hidrokarbon 
berupa konsep dan uraian sehingga diperlukan pemahaman yang mendalam dari peserta didik. Peserta didik sulit dalam menelaah dan menalar konsep materi yang berkaitan dengan hidrokarbon. Terlihat dari hasil wawancara dengan Guru Kimia Kelas XI MIPA SMA Negeri 2 Sidrap bahwa ketuntasan kelas pada materi pokok hidrokarbon hanya 50\% mencapai nilai kriteria ketuntasan minimal (KKM) yang telah ditetapkan, yakni 75 di tahun ajaran 2016-2017. Adapun faktor yang menyebabkan hal tersebut yaitu penggunaan model pembelajaran yang masih bersifat konvensional yang bersifat berpusat pada guru sehingga peserta didik kurang termotivasi dalam pembelajaran. Hal ini berdampak pada rendahnya hasil belajar yang digambarkan melalui ketuntasan kelas di SMA Negeri 2 Sidrap.

Oleh sebab itu, dibutuhkan model pembelajaran agar peserta didik mampu saling bertukar pikiran satu sama lain dalam penyajian materi kimia yang menarik. Selain itu dengan hal tersebut pula peserta didik tidak cepat merasa bosan. Sehingga dapat membantu peserta didik dalam mengatasi kesulitan belajar dan menghilangkan persepsi buruk serta paradigma awal peserta didik akan pelajaran kimia yang sulit. Perubahan paradigma dalam pembelajaran ini diharapkan dapat mendorong peserta didik untuk termotivasi dalam membangun pengetahuan, sikap dan perilaku. Berdasarkan hal tersebut diperlukan suatu upaya melalui suatu pembelajaran yang mampu membawa perubahan ke arah yang lebih baik. Sehingga pendekatan scientific digunakan sebagai pedoman umum dalam menyusun langkahlangkah metode pembelajaran yang akan digunakan dan memberikan garis rujukan untuk perancangan model pembelajaran. Salah satu contoh model pembelajaran yang berpusat pada peserta didik (student centered) yaitu Model Pembelajaran Kooperatif tipe $\mathrm{CRH}$

Model pembelajaran kooperatif tipe $\mathrm{CRH}$ merupakan model pembelajaran yang dapat menciptakan suasana kelas menjadi meriah dan menyenangkan karena setiap kelompok yang dapat menjawab benar maka peserta didik tersebut diwajibkan berteriak "HOREY" atau yel-yel lainnya yang disukai (Huda, 2013). Dengan model pembelajaran kooperatif tipe $\mathrm{CRH}$ dengan pendekatan scientific dapat meningkatkan motivasi peserta didik dalam mengikuti pelajaran kimia sebab peserta didik lebih aktif dalam proses pembelajaran dan terjalinnya kerja sama yang baik antar peserta didik sehingga hasil belajar akan dicapai secara maksimal. Berdasarkan uraian tersebut, rumusan masalah yang diteliti oleh peneliti adalah apakah ada pengaruh model pembelajaran kooperatif tipe $\mathrm{CRH}$ dengan pendekatan Scientific terhadap motivasi dan hasil belajar peserta didik kelas XI MIPA SMA Negeri 2 Sidrap pada materi pokok Hidrokarbon?.

Tujuan penelitian ini adalah untuk mengetahui pengaruh model pembelajaran kooperatif tipe $\mathrm{CRH}$ dengan pendekatan Scientific terhadap motivasi dan hasil belajar peserta didik 
kelas XI MIPA SMA Negeri 2 Sidrap pada materi pokok Hidrokarbon.

\section{METODE PENELITIAN}

Penlitian ini merupakan penelitian eksperimen semu dengan posttest-only control group design untuk motivasi belajar dan pretest posttest-only control group design untuk hasil belajar. Populasi dalam penelitian ini adalah siswa kelas XI MIPA SMA Negeri 2 Sidrap yang terdiri dari lima kelas. Sampel yang digunakan dalam penelitian ini terdiri dari dua kelas yaitu kelas XI MIPA 1 sebagai kelas eksperimen dan kelas XI MIPA 2 sebagai kelas kontrol. Sampel ditentukan melalui class random sampling.

Instrumen yang digunakan terdiri atas 2 instrumen yaitu angket motivasi dan tes hasil belajar berupa soal pilihan ganda yang terdiri atas 26 butir soal. Teknik analisis dengan cara analisis statistik deskriptif dan analisis statistik inferensial. Sebelum dilakukan uji hipotesis maka terlebih dahulu dilakukan uji prasyarat yaitu uji normalitas dan uji homogenitas. Untuk motivasi belajar pengujian hipotesis dilakukan dengan menggunakan statistik parametrik (uji-t) sedangkan untuk hasil belajar pengujian hipotesis menggunakan statistik non-parametrik (mann-whitney).

\section{HASIL DAN PEMBAHASAN}

\section{A. Hasil Penelitian}

\section{Motivasi Belajar Peserta Didik}

Analisis statistik deskriptif motivasi digunakan untuk memberikan gambaran umum mengenai motivasi belajar peserta didik di kelas eksperimen dan kelas kontrol. Data hasil analisis deskriptif dapat dilihat pada Tabel 1.

Tabel 1 menunjukkan perbedaan deskriptif antara kelas eksperimen dan kelas kontrol, yaitu nilai terendah dan nilai tertinggi pada kelas eksperimen lebih tinggi daripada kelas kontrol. Selain itu peserta didik pada kelas eksperimen memperoleh nilai rata-rata lebih tinggi dibandingkan dengan kelas kontrol, yaitu dengan selisih 5,66. Begitupula dengan nilai median serta modus, kelas eksperimen memperoleh nilai yang lebih tinggi dibandingkan dengan kelas kontrol.

Tabel 1. Hasil Analisis Deskriptif Motivasi Belajar Peserta Didik pada Kelas Eksperimen dan Kelas Kontrol

\begin{tabular}{ccc}
\hline \multirow{2}{*}{ Statistik } & \multicolumn{2}{c}{ Nilai Statistik } \\
\cline { 2 - 3 } & $\begin{array}{c}\text { Kelas } \\
\text { Eksperimen }\end{array}$ & $\begin{array}{c}\text { Kelas } \\
\text { Kontrol }\end{array}$ \\
\hline Jumlah Sampel & 36 & 36 \\
\hline Nilai Terendah & 62 & 54 \\
\hline Nilai Tertinggi & 97 & 91 \\
\hline $\begin{array}{c}\text { Nilai Rata-Rata } \\
\text { (Mean) }\end{array}$ & 80,33 & 74,67 \\
\hline $\begin{array}{c}\text { Median (Me) } \\
\text { Modus (Mo) }\end{array}$ & 80,50 & 76,70 \\
\hline $\begin{array}{c}\text { Varians (S2) } \\
\text { Standar Deviasi } \\
(\mathrm{S})\end{array}$ & 80,54 & 78,59 \\
\hline
\end{tabular}

Selanjutnya nilai motivasi belajar peserta didik dibagi dalam beberapa kategori motivasi belajar. Frekuensi serta persentase tiap kategori motivasi belajar dapat dilihat pada Tabel 2.

Tabel 2 diatas menunjukkan bahwa pada kategori sangat tinggi, kelas eksperimen memperoleh 
frekuensi serta persentase yang sangat jauh lebih tinggi dibandingkan dengan kelas kontrol, sedangkan pada kategori tinggi, sedang, dan rendah kelas kontrol memiliki frekuensi dan persentase yang lebih tinggi daripada kelas eksperimen.

Tabel 2. Frekuensi dan Kategori Motivasi

\begin{tabular}{ccccc}
\hline \multirow{2}{*}{ Kategori } & \multicolumn{2}{c}{ Kelas Eksperimen } & \multicolumn{2}{c}{ Kelas Kontrol } \\
\cline { 2 - 5 } & Frekuensi & Persentase(\%) & Frekuensi & Persentase(\%) \\
\hline Sangat Tinggi & 13 & 36,11 & 4 & 11,11 \\
\hline Tinggi & 18 & 50,00 & 20 & 55,56 \\
\hline Sedang & 5 & 13,89 & 11 & 30,56 \\
\hline Rendah & 0 & 0 & 1 & 2,77 \\
\hline Sangat Rendah & 0 & 0 & 0 & 0 \\
\hline & & & 1,083 & dan Ftabel $=1,757$ pada taraf
\end{tabular}

Uji normalitas yang digunakan dalam penelitian ini adalah uji chi kuadrat, dengan kriteria data terdistribusi normal jika $\chi^{2}$ hitung < $\chi_{\text {tabel. }}^{2} \quad$ Nilai untuk $\chi_{\text {tabel }}^{2}$ yang digunakan pada kelas eksperimen dan kelas kontrol adalah pada taraf signifikan $=0,05$ dan derajat kebebasan $(\mathrm{dk})=4$, sehingga diperoleh $\chi_{\text {tabel }}^{2}=9,49$. Untuk kelas eksperimen diperoleh $\chi^{2}$ hitung $=6,14$, yang artinya nilai $\chi^{2}$ hitung $<\chi^{2}$ tabel, sehingga dapat disimpulkan bahwa data dari kelas eksperimen terdistribusi normal. Selanjutnya untuk kelas kontrol diperoleh $\chi^{2}$ hitung $=3,82$, yang artinya $\chi^{2}$ hitung $<\chi_{\text {tabel, }}^{2}$ sehingga dapat disimpulkan bahwa data dari kelas kontrol terdistribusi normal.

Uji homogenitas digunakan untuk mengetahui apakah kedua kelompok yan diteliti berasal dari populasi yang homogen atau tidak. Kriteria pengujian homogenitas yang digunakan adalah jika Fhitung < Ftabel maka kedua kelas sampel berasal dari populasi yang homogen. Dari hasil perhitungan diperoleh nilai Fhitung = signifikan 0,05. Karena Fhitung < Ftabel maka dapat disimpulkan bahwa varians pada kelas eksperimen dan kelas kontrol berasal dari populasi yang homogen.

Perhitungan uji hipotesis dilakukan untuk mengetahui ada tidaknya pengaruh model pembelajaran kooperatif tipe $\mathrm{CRH}$ dengan pendekatan scientific terhadap motivasi belajar peserta didik. Setelah diketahui bahwa skor motivasi belajar peserta didik kelas eksperimen dan kelas kontrol terdistribusi normal, serta kedua kelas berasal dari populasi yang homogen, maka pada uji hipotesis digunakan uji-t satu pihak.

Dari hasil perhitungan motivasi belajar menggunakan uji-t diperoleh nilai thitung $=2,77$ dan nilai ttabel pada taraf signifikan 0,05 dan dk $=70$ sebesar 1,99 yang berarti, nilai thitung > ttabel. Hal ini menunjukkan bahwa Ho ditolak dan $\mathrm{H} 1$ diterima dan disimpulkan bahwa ada pengaruh model pembelajaran kooperatif tipe CRH dengan pendekatan scientific terhadap motivasi belajar peserta didik 
SMA Negeri 2 Sidrap pada materi pokok Hidrokarbon.

\section{Hasil Belajar Peserta Didik}

Analisis statistik deskriptif digunakan untuk memberikan gambaran umum mengenai karakteristik data pencapaian hasil belajar peserta didik kelas eksperimen dan kelas kontrol. Hasil belajar yang digunakan dalam penelitian ini yaitu N-Gain. Uji Normal Gain dilakukan untuk melihat peningkatan hasil belajar peserta didik setelah pembelajaran dilakukan. Uji Normal Gain dilakukan dengan cara menghitung selisih antara nilai pretest dan posttest yang dicapai oleh peserta didik. Data hasil penghitungan skor Normal Gain pada kelas eksperimen dan kelas kontrol dapat dilihat pada Tabel 3.

Tabel 3 memperlihatkan bahwa kelas eksperimen memiliki ratarata $\mathrm{N}-$ Gain yaitu 0,870 sedangkan kelas kontrol yaitu 0,805 . Rata-rata NGain yang diperoleh dari kelas eksperimen dan kelas kontrol berada pada kategori tinggi (nilai $(\mathrm{g}) \geq 0,7$ ) yang berarti ketuntasan proses pembelajaran berhasil dilakukan, akan tetapi perbedaan pada kelas eksperimen dan kelas kontrol terletak pada nilai rata-rata $\mathrm{N}$-Gain dimana kelas eksperimen lebih tinggi dari kelas kontrol. Hal ini berarti kelas eksperimen yang di ajar dengan menggunakan model pembelajaran kooperatif tipe $\mathrm{CRH}$ dengan pendekatan scientific mengalami peningkatan hasil belajar yang lebih tinggi dibandingkan kelas kontrol yang di ajar dengan menggunakan model pembelajaran langsung.

Tabel 3. Hasil Perhitungan Normal Gain

\begin{tabular}{ccc}
\hline Normal Gain & $\begin{array}{c}\text { Kelas } \\
\text { Eksperimen }\end{array}$ & $\begin{array}{c}\text { Kelas } \\
\text { Kontrol }\end{array}$ \\
\hline $\begin{array}{c}\text { Ukuran } \\
\text { Sampel }\end{array}$ & 36 & 36 \\
\hline Terendah & 0,429 & 0,136 \\
\hline Tertinggi & 1,000 & 0,947 \\
\hline Rata-rata & 0,860 & 0,774 \\
\hline $\begin{array}{c}\text { Standar } \\
\text { Deviasi }\end{array}$ & 0,147 & 0,164 \\
\hline Varians $\left(\mathrm{S}^{2}\right)$ & 0,021 & 0,027 \\
\hline
\end{tabular}

Data pengkategorian N-Gain pada kelas eksperimen dan kelas kontrol disajikan dalam Tabel 4.

Tabel 4. Kategori N-Gain

\begin{tabular}{ccccccc}
\hline \multirow{2}{*}{ Kelas } & \multicolumn{5}{c}{ Perolehan N-Gain } \\
\cline { 2 - 7 } & Tinggi & Sedang & Rendah & Tinggi & Sedang & Rendah \\
\hline \multirow{nyyyyyy}{*}{ Eksperimen } & 30 & 6 & - & 83,33 & 16,67 & - \\
\hline Kontrol & 29 & 6 & 1 & 80,55 & 16,67 & 2,78 \\
\hline
\end{tabular}


Tabel 4 menunjukkan bahwa hasil belajar peserta didik pada kelas eksperimen lebih tinggi dibandingkan dengan hasil belajar peserta didik di kelas kontrol.

Berdasarkan keseluruhan nilai yang diperoleh peserta didik pada kelas eksperimen dan kelas kontrol, jika hasil belajar peserta didik dikelompokkan dalam kategori ketuntasan hasil belajar berdasarkan standar ketuntasan belajar kimia kelas XI MIPA SMA Negeri 2 Sidrap, maka diperoleh data frekuensi dan persentase ketuntasan hasil belajar peserta didik seperti pada Tabel 5.

Tabel 5 menunjukkan bahwa ketuntasan hasil belajar peserta didik pada materi hidrokarbon untuk kelas eksperimen dan kelas kontrol telah memenuhi kriteria ketuntasan kelas yang ditetapkan sekolah yakni 75,00.

Tabel 5. Kategori Ketuntasan Hasil Belajar Peserta Didik

\begin{tabular}{cccccc}
\hline \multirow{2}{*}{ Kategori } & \multirow{2}{*}{ Nilai } & \multicolumn{2}{c}{ Kelas Eksperimen } & \multicolumn{2}{c}{ Kelas Kontrol } \\
\cline { 3 - 6 } & Frekuensi & Persentase(\%) & Frekuensi & Persentase(\%) \\
\hline Tuntas & $\geq 75$ & 36 & 100 & 36 & 100 \\
$\begin{array}{c}\text { Tidak } \\
\text { Tuntas }\end{array}$ & $<75$ & 0 & 0 & 0 & 0 \\
\hline \multicolumn{2}{c}{ Jumlah } & 36 & 100 & 36 & 100
\end{tabular}

Uji normalitas yang digunakan dalam penelitian ini adalah uji chi kuadrat, dengan kriteria data terdistribusi normal jika $\chi 2$ hitung $<$ $\chi 2$ tabel. Nilai untuk $\chi 2$ tabel yang digunakan pada kelas eksperimen dan kelas kontrol adalah pada taraf signifikan $=0,05$ dan derajat kebebasan $(\mathrm{dk})=4$, sehingga diperoleh $\chi 2$ tabel $=9,49$. Dari hasil perhitungan untuk kelas eksperimen diperoleh $\chi 2$ hitung $=46,68$, yang artinya nilai $\chi 2$ hitung $>\chi 2$ tabel, sehingga dapat disimpulkan bahwa data dari kelas eksperimen tidak terdistribusi normal. Selanjutnya untuk kelas kontrol diperoleh $\chi 2$ hitung $=42,02$, yang artinya $\chi 2$ hitung $>\chi 2$ tabel, sehingga dapat disimpulkan bahwa data dari kelas kontrol tidak terdistribusi normal. untuk mengetahui apakah kedua kelompok yan diteliti berasal dari populasi yang homogen atau tidak. Kriteria pengujian homogenitas yan digunakan adalah jika Fhitung < Ftabel maka kedua kelas sampel berasal dari populasi yang homogen. Dari hasil perhitungan diperoleh nilai Fhitung = 1,188 dan Fhitung $=1,757$ pada taraf signifikan 0,05. Karena Fhitung < Ftabel maka dapat disimpulkan bahwa varians pada kelas eksperimen dan kelas kontrol berasal dari populasi yang homogen.

Perhitungan uji hipotesis 2 dilakukan untuk mengetahui ada tidaknya pengaruh model pembelajaran kooperatif tipe $\mathrm{CRH}$ dengan pendekatan scientific terhadap hasil belajar peserta didik. Setelah diketahui bahwa data N-Gain dari 
kelas eksperimen dan kelas kontrol tidak terdistribusi normal, serta kedua kelas berasal dari populasi yang homogen, maka pada uji hipotesis 2 tidak dapat menggunakan uji-t satu pihak. Pengujian hipotesis dilakukan dengan uji statistic non-parametrik, yaitu uji Mann-Whitney.

Dari hasil perhitungan N-Gain menggunakan uji Mann-Whitney, diperoleh Zhitung $=2,866$ dan nilai Ztabel pada taraf signifikan 0,05 sebesar 1,64 yang berarti, nilai Zhitung $>$ Ztabel. Hal ini menunjukkan bahwa Ho ditolak dan H1 diterima dan disimpulkan bahwa ada pengaruh model pembelajaran kooperatif tipe $\mathrm{CRH}$ dengan pendekatan scientific terhadap hasil belajar peserta didik SMA Negeri 2 Sidrap pada materi pokok Hidrokarbon.

\section{B. Pembahasan}

Penelitian ini bertujuan untuk mengetahui pengaruh model pembelajaran kooperatif tipe $\mathrm{CRH}$ dengan pendekatan scientific terhadap motivasi dan hasil belajar peserta didik. Dalam penelitian ini, peneliti membandingkan motivasi belajar dan hasil belajar peserta didik yang diberi model pembelajaran kooperatif tipe $\mathrm{CRH}$ dengan pendekatan scientific pada kelas eksperimen dengan peserta didik yang diberi model pembelajaran langsung pada kelas kontrol

\section{Motivasi Belajar Peserta Didik}

Salah satu tujuan dari penelitian ini untuk mengetahui pengaruh motivasi belajar peserta didik dengan menggunakan model pembelajaran $\mathrm{CRH}$ pada kelas eksperimen terhadap model pembelajaran langsung pada kelas kontrol. Teknik pengumpulan data motivasi belajar melalui angket dimana terdiri dari 8 indikator yang dibagi ke dalam 30 item. Telah diperoleh hasil kategori ketuntasan indikator motivasi belajar kelas Eksperimen dan kontrol. Adapun hasil yang di peroleh dimana pada kelas eksperimen, semua indikator berada pada kategori tinggi kecuali pada indikator "memiliki minat terhadap pelajaran" yang berada pada kategori sangat tinggi dan indikator "lebih senang kerja mandiri" berada pada kategori sedang. Adapun pada indikator "memiliki minat terhadap pelajaran" berada pada kategori sangat tinggi disebabkan karena materi hidrokarbon merupakan materi yang hanya berdasarkan pada konsepkonsep tanpa perhitungan rumusrumus yang rumit, apalagi dengan menggunakan model pembelajaran $\mathrm{CRH}$ dengan pendekatan scientific peserta didik mampu dengan mudah memahami konsep-konsep hidrokarbon. Selain itu, pada indikator "lebih senang kerja mandiri" berada pada kategori sedang disebabkan peserta didik cenderung menyukai bekerja secara berkelompok dibandingkan bekerja secara mandiri.

Pada kelas kontrol, semua indikator berada pada kategori tinggi kecuali pada indikator "lebih senang kerja mandiri" dan indikator "tidak mudah melepas hal yang diyakini" berada pada kategori sedang. Adapun pada indikator "lebih senang kerja mandiri" berada pada kategori sedang disebabkan sama halnya dengan kelas 
eksperimen dimana peserta didik cenderung lebih menyukai bekerja secara berkelompok dibandingkan bekerja secara mandiri. Selain itu pada indikator "tidak mudah melepas hal yang diyakini" berada pada kategori sedang disebabkan peserta didik masih kurang percaya diri dalam menjawab soal yang disampaikan oleh guru, dan cenderung lebih percaya ke jawaban temannya.

Adapun rata-rata ketuntasan tiap indikator yang diperoleh dimana kelas eksperimen memiliki rata-rata 79,21 sedangkan kelas kontrol memiliki rata-rata 73,16 . Hal ini berarti rata-rata ketuntasan tiap indikator kelas eksperimen lebih tinggi dari pada rata-rata ketuntasan tiap indikator kelas kontrol. Berdasarkan hasil analisis deskriptif data motivasi belajar peserta didik diperoleh bahwa nilai rata-rata pada kelas eksperimen lebih tinggi darpada kelas kontrol yaitu 80,33 untuk kelas eksperimen dan 74,67 untuk kelas kontrol.

Dari beberapa hasil yang diperoleh dapat disimpulkan bahwa peserta didik pada kelas eksperimen memiliki motivasi belajar yang tinggi dibandingkan kelas kontrol. Hal ini disebabkan adanya model pembelajaran kooperatif tipe $\mathrm{CRH}$ yang diterapkan dimana peserta didik memperoleh suasana belajar yang belum peserta didik dapatkan sebelumnya yang memacu peserta didik lebih termotivasi dalam belajar. Model ini juga mendorong peserta didik untuk semangat dalam belajar, hal ini dikarenakan kondisi belajar yang menyenangkan dimana peserta didik melakukan permainan $\mathrm{CRH}$.
Permainan $\mathrm{CRH}$ membuat peserta didik semangat dalam mengerjakan soal dalam permainan untuk mengumpulkan poin sebanyak mungkin, sehingga semangat itu mendorong motivasi peserta didik dalam mengikuti proses pembelajaran yang berlangsung. Hal ini juga akan mendorong motivasi peserta didik untuk bekerja sama dalam kelompoknya.

Adapun hasil yang diperoleh didukung oleh data keterlaksanaan model pembelajaran, seluruh langkahlangkah pembelajaran terlaksana dengan baik. Data ini juga dapat didukung dari persentase keaktifan peserta didik. Adapun persentase aktivitas belajar peserta didik pada masing-masing kelas diperoleh bahwa rata-rata persentase keaktifan di kelas eksperimen lebih tinggi yaitu 88,13\% dengan kategori "sangat aktif" sedangkan pada kelas kontrol yaitu $70,7 \%$ dengan kategori "aktif". Berdasarkan data ini dapat disimpulkan bahwa peserta didik yang diberikan model pembelajara kooperatif tipe $\mathrm{CRH}$ dengan pendekatan scientific lebih antusias untuk belajar karena dapat membuat motivasi belajar peserta didik lebih meningkat.

Dari hasil analisis statistik inferensial, dinyatakan bahwa data dari kelas eksperimen dan kontrol berasal dari populasi yang terdistribusi normal dan homogen, sehingga pengujian hipotesis dengan uji-t dapat dilanjutkan. Hasil pengujian tersebut memberikan kesimpulan bahwa $\mathrm{H} 0$ ditolak dan H1 diterima, artinya dengan adanya model pembelajaran 
kooperatif tipe CRH dengan pendekatan scientific, memberikan pengaruh positif terhadap motivasi belajar peserta didik pada SMA Negeri 2 Sidrap kelas XI MIPA.

\section{Hasil Belajar Peserta Didik}

Penelitian ini dilakukan untuk mengetahui adanya pengaruh model pembelajaran kooperatif tipe $\mathrm{CRH}$ dengan pendekatan scientific terhadap hasil belajar peserta didik. Hasil belajar diperoleh dari N-Gain peserta didik setelah dibelajarkan dengan menggunakan model pembelajaran kooperatif tipe $\mathrm{CRH}$ dengan pendekatan scientific untuk kelas eksperimen sedangkan untuk kelas kelas kontrol dengan menggunakan model pembelajaran langsung.

Jumlah peserta didik yang tuntas pada kelas eksperimen dan kelas konrol sama. Persentase ketuntasan untuk kelas eksperimen dan kontrol sebesar $100 \%$. Akan tetapi perbedaan yang muncul pada hasil N-Gain. NGain digunakan untuk mengetahui peningkatan hasil pretest dan posttest. Perolehan N-Gain pada kelas eksperimen berada pada kategori tinggi sebesar $83,33 \%$ dan pada kelas kontrol berada pada kategori tinggi sebesar $80,55 \%$ yang membuktikan bahwa adanya peningkatan penguasaan peserta didik terhadap materi yang disajikan. Hasil N-Gain kelas ekperimen dan kelas kontrol berada pada kategori yang sama akan tetapi memiliki nilai rata-rata persentase yang berbeda dimana kelas ekperimen lebih tinggi dari kontrol yang dapat disimpulkan bahwa hasil belajar kelas eksperimen yang dibelajarkan dengan model pembelajaran kooperatif dengan pendekatan scientific lebih baik daripada kelas kontrol yang dibelajarkan dengan model pembelajaran langsung. Penggunaan model pembelajaran kooperatif tipe $\mathrm{CRH}$ dengan pendekatan scientific memberikan hasil belajar yang lebih baik dibandingkan dengan model pembelajaran langsung disebabkan karena selama proses pembelajaran berlangsung mampu melibatkan peserta didik secara aktif dalam kelas. Data menunjukkan untuk kelas eksperimen keaktifan peserta didik berada pada kategori sangat aktif terlihat pada aktivitas yang diamati pada permainan CRH terdapat 6 aspek yang memiliki persentase di atas $65 \%$. Ketiga aspek lainnya memiliki persentase yang kurang dari $65 \%$ menunjukkan bahwa keaktifan peserta didik pada aspek tersebut berada pada kategori kurang. Kurangnya keaktifan peserta didik pada aspek tersebut karena sebagian peserta didik masih kurang memiliki rasa percaya diri untuk mengemukakan pendapat mereka di depan kelas, peserta didik kurang berani jika saja jawaban yang mereka ajukan salah dan tidak sesuai dengan yang diharapkan. Namun, secara umum dari pertemuan I sampai IV terlihat peningkatan aktivitas dari semua indikator aktivitas yang diamati.

Pada kelas kontrol, keaktifan peserta didik berada pada kategori aktif dibandingkan dengan kelas eksperimen berada pada kategori sangat aktif. Adanya hal tersebut karena penggunaan model pembelajaran langsung yang peserta 
didik sudah pernah dapatkan sebelumnya, sehingga tidak ada hal yang baru untuk peserta didik agar lebih termotivasi untuk lebih aktif dalam proses pembelajaran. Adapun untuk kelas kontrol terdapat aspek yang memiliki kategori kurang aktif karena sebagian peserta didik masih kurang memiliki rasa percaya diri untuk memberikan komentar terhadap jawaban teman mereka yang berbeda dengan jawabannya sendiri, peserta didik kurang berani memberikan kritikan mereka karena merasa takut jika jawaban yang mereka komentari ternyata sudah benar dan malah jawabannya yang salah, serta peserta didik kurang rajin untuk mencatat materi yang dipelajari.

Persentase rata-rata keaktifan peserta didik menunjukkan pada kelas eksperimen keaktifan peserta didik lebih tinggi dibandingkan kelas kontrol. Hal ini dapat terlihat dari antusias peserta didik selama proses kegiatan pembelajaran, dimana mereka termotivasi dengan adanya inovasi baru dalam pembelajaran yakni dengan model pembelajaran kooperatif tipe CRH. Permainan CRH yang dilakukan menyebabkan efektifnya proses kegiatan pembelajaran dimana dapat meningkatkan motivasi peserta didik selain itu juga merangsang peserta didik mengingat apa yang sudah dipelajari, serta mengaktifkan peserta didik dalam mengikuti proses pembelajaran. Model pembelajaran kooperatif tipe $\mathrm{CRH}$ juga meningkatkan kerja sama peserta didik dalam mengerjakan soal pada permainan CRH dimana peserta didik saling mengajarkan satu sama lain yang mana peserta didik yang sudah mengerti mengajari peserta didik yang belum mengerti pada saat diskusi kelompok, kemudian peserta didik mempresentasikan soal yang telah mereka jawab dan guru memberikan penguatan materi atas jawaban tersebut. Kemudian, pada akhir pembelajaran guru memberikan evaluasi kepada peserta didik untuk menguji kemampuan peserta didik mengenai materi yang telah dipelajari.

Selain data tentang hasil belajar, diperoleh pula data persentase pencapaian tiap indikator pada materi hidrokarbon untuk kelas eksperimen dan kontrol. Persentase pencapaian tiap indikator untuk kelas eksperimen, dari tujuh indikator terlihat semua indicator termasuk kategori tuntas. Sedangkan untuk kelas kontrol, dari tujuh indikator terdapat dua indikator yang tidak tuntas. Indikator yang tidak tuntas pada kelas kontrol adalah menentukan isomer struktur (kerangkan, posisi, fungsi) dan/atau isomer geometri (cis, trans) dengan persentase ketuntasan $67,78 \%$ serta menuliskan reaksi sederhana pada senyawa alkana, alkena, dan alkuna (reaksi oksidasi, reaksi adisi, reaksi substitusi, dan reaksi eliminasi) dengan persentase ketuntasan hanya 68,06\%. Hal ini karena sebagian besar peserta didik pada kelas ini merasa kesulitan dalam menentukan isomer dan senyawa hidrokarbon dimana memerlukan penalaran yang tinggi untuk menentukan isomernya, serta peserta didik merasa kesulitan dalam menuliskan reaksi pada senyawa hidrokarbon seperti menuliskan reaksi oksidasi, reaksi adisi, reaksi substitusi, 
atau menuliskan reaksi eliminasi dibuktikan pada proses pembelajaran peserta didik kebingungan dalam memahami materi tersebut.

$$
\text { Berdasarkan pengujian }
$$

analisis prasyarat (uji normalitas dan uji homogenitas), dinyatakan bahwa data dari kelas eksperimen dan kontrol berasal dari populasi yang tidak berdistribusi normal namun kedua kelompok berasal dari varians yang homogen, sehingga pengujian hipotesis dengan menggunakan uji $\mathrm{t}$ tidak dapat dilanjutkan. Adapun alternatif lain untuk pengujian hipotesis untuk data yang tidak berdistribusi normal yaitu dengan menggunakan pengujian hipotesis nonparametrik (uji Mann-Whitney). Hasil pengujian hipotesis dengan mengguanakan uji Mann-Whitney untuk hasil belajar diperoleh nilai Zhitung $=2,866$ dan nilai Ztabel pada taraf kepercayaan 0,05 sebesar 1,64. Ini menunujukkan bahwa nilai Zhitung > Ztabel yang berarti hipotesis yang daijukan diterima. Dengan demikian, dapat disimpulkan bahwa model pembelajaran kooperatif tipe $\mathrm{CRH}$ dengan pendekatan scientific berpengaruh positif terhadap hasil belajar peserta didik kelas XI MIPA SMA Negeri 2 Sidrap pada materi pokok hidrokarbon.

Berdasarkan pengujian hipotesis yang dilakukan, dapat dikatakan bahwa model pembelajaran kooperatif tipe CRH degan pendekatan scientific berpengaruh positif terhadap hasil belajar peserta didik kelas XI MIPA SMA Negeri 2 Sidrap pada materi pokok hidrokarbon. Hal ini didukung hasil penelitian yang telah dilakukan oleh Ni Made Marteni, dkk (2013) menyatakan bahwa hasil belajar peserta didik dengan model pembelajaran kooperatif tipe $\mathrm{CRH}$ dapat meningkatkan persentase hasil belajar peserta didik. Selain itu model pembelajaran kooperatif tipe $\mathrm{CRH}$ juga dapat meningkatkan motivasi belajar peserta didik, hal ini didukung oleh penelitian yang dilakukan oleh Sulistiyanti (2012) dimana model pembelajaran kooperatif tipe $\mathrm{CRH}$ dapat memberikan pengaruh positif motivasi dan hasil belajar peserta didik,

Beberapa kendala yang dialami peneliti dalam penggunaan model pembelajaran kooperatif tipe $\mathrm{CRH}$ dengan pendekatan scientific adalah permainan $\mathrm{CRH}$ yang terkesan sesuatu yang baru bagi peserta didik sehingga guru perlu memberi pengenalan terlebih dahulu, dibuktikan pada pertemuan pertama guru masih kesulitan dalam mengelola permainan yang sistematis dan tertib dikarenakan peserta didik masih kebingungan dalam melakukan permainan. Hal ini disebabkan karena mereka belum terbiasa dan hanya mendengarkan pelajaran secara langsung dari guru, selain itu model pembelajaran kelompok yang diterapkan juga berbeda dari kelompok biasanya seperti peserta didik dibagi kedalam kelompok-kelompok yang heterogen dan banyak peserta didik yang ingin mencari sendiri teman kelompoknya dimana beberapa peserta didik hanya ingin berkelompok dengan teman yang mereka anggap akrab dan mudah untuk diajak bekerjasama. Kendala lain, yaitu keterbatasan waktu dimana 
langkah permainan CRH yang begitu padat hal itu jg dikarenakan pengerjaan soal oleh peserta didik, presentasi oleh peserta didik, dan penguatan oleh guru membutuhkan waktu yang lama, namun karena disesuaikan dengan alokasi waktu yang tersedia sehingga terkadang ada soal yang tidak di presentasi oleh peserta didik melainkan guru menjawab langsung soal tersebut. Hal ini disebabkan karena waktu yang dibutuhkan dengan model pembelajaran kooperatif tipe $\mathrm{CRH}$ dengan pendekatan scientific relatif lebih banyak apalagi pembelajaran secara berkelompok memerlukan pengelolaan kelas yang menyita waktu lebih banyak.

\section{KESIMPULAN DAN SARAN}

\section{A. Kesimpulan}

Berdasarkan hasil analisis data dan pembahasan maka dapat disimpulkan bahwa

1. Ada pengaruh positif model pembelajaran kooperatif tipe $\mathrm{CRH}$ dengan pendekatan scientific terhadap motivasi belajar peserta didik kelas XI MIPA SMA Negeri 2 Sidrap pada materi pokok hidrokarbon.

2. Ada pengaruh positif model pembelajaran kooperatif tipe $\mathrm{CRH}$ dengan pendekatan scientific terhadap hasil belajar peserta didik kelas XI MIPA SMA Negeri 2 Sidrap pada materi pokok hidrokarbon.

\section{B. Saran}

Berdasarkan hasil yang diperoleh dari penelitian ini, maka dikemukakan saran yaitu Guru diharapkan dapat mengatur waktu dengan baik ketika ingin menggunakan model pembelajaran kooperatif tipe $\mathrm{CRH}$ dengan pendekatan scientific ini, karena dibutuhkan pengelolaan waktu yang lebih lama dari pembelajaran umumnya. Selain itu guru diharapkan terlebih dahulu menjelaskan kepada peserta didik mengenai model pembelajaran yang digunakan kepada peserta didik karena peserta didik belum terbiasa dengan penggunaan model pembelajaran kooperatif tipe CRH dengan pendekatan scientific.

\section{DAFTAR PUSTAKA}

Harianto. 2012. Pengaruh Strategi Pembelajaran Course Review Horay Menggunakan Puzzle Terhadap Hasil Belajar Siswa pada Standar Kompetensi Menerapkan Dasar-dasar Elektronika di SMK. Jurnal Pendidikan Elektro, Volume 02, Nomor 1. Diakses pada tanggal : 1 Oktober 2016

Huda, Miftahul. 2013. Model-Model Pengajaran dan Pembelajaran . Yogyakarta. Pustaka Pelajar.

Isjoni. 2013. Cooperative Learning. Bandung : Alfabeta.

Kemendikbud. 2013. Pengembangan kurikulum 2013. Jakarta: kemendikbud.

Marteni, Partini, dan Riastini. 2013. Pengaruh Model Pembelajaran Kooperatif Tipe Course Review Horay (Crh) Terhadap Hasil Belajar Ipa Pada Siswa Kelas V SD Tahun Pelajaran 2013/2014. Jurnal PGSD. Vol. 1, No.2. Diakses pada tanggal : 1 Oktober 2016. 